\title{
RECESSED BALCONY HEAT RE-ENTRY EFFECT ON FAÇADE WITH CONDENSER UNITS
}

\author{
Kevin Yonathan Tanumidjaja ${ }^{1^{*}}$, Danny Santoso Mintorogo $^{2}$, Rully Damayanti $^{3}$ \\ ${ }^{1}$ Master Student, Department of Architecture, Petra Christian University, \\ Jl. Siwalankerto 121-131, Surabaya 60236, Indonesia \\ ${ }^{2,3}$ Department of Architecture, Petra Christian University, Jl. Siwalankerto 121-131, Surabaya 60236, Indonesia \\ *Corresponding author; Email: kevin.tanumidjaja@gmail.com
}

\begin{abstract}
The use of split-type air conditioner in Surabaya results in the almost universal typical apartment layouts which feature a recessed balcony upon the building's exterior façade which then utilized as air-conditioner condenser unit storage. Façade geometry with recessed balcony itself carries its own characteristic of surface air movement which affects the general Indoor Air Quality (IAQ) and heat dissipation of a building. Nevertheless, façade as architectural elements greatly influence building's energy performance. Inefficiencies in heat dissipation from a condenser unit is detrimental on its performance and precipitate energy wastage. Based on computational fluid dynamics (CFD) analysis incorporated with energy performance evaluation, the effectiveness of façade geometry with recessed balcony is explored in this paper. It was found that recessed balconies are not an ideal place for condenser unit placement on a façade where many factors contributed to promoting heat re-entry from condenser units into the building's interior.
\end{abstract}

Keywords: Thermal comfort; CFD application; high-rise building; condenser; recessed balcony.

\section{INTRODUCTION}

Building design of residential high-rise apartment in Surabaya almost universally follows a typical form largely influenced by economics to promote efficiency and maximizing space resulting from highly competitive real estate markets. Few if any residential buildings in Surabaya and to a large extent Indonesia as a whole deviate from the commonly adopted layouts albeit any slight design variations. These high-rise apartments marketed for middle income household are designed to emulate landed properties in a much smaller and limited floor area and equipped with outdoor space as required by government regulations (Peraturan Menteri Pekerjaan Umum no.29 Tahun 2006) to provide residents an indoor - outdoor interaction space as well as improving thermal comfort through overhang effect (Ribiero, 2020.) However, recessed balconies are utilized to accommodate the placement of condenser units to maximize space utilization despite the heat produced by the device. Another hallmark design element of the apartment is the use of extruded aluminum window frames on the façade which includes the balcony area. This window frames often features less than ideal insulation resulting in air leakage both from inside and outside of the façade. The geometry itself facilitates the formation of air pressure pushing inward on façade surfaces, magnifying air leakage through the cracks in windows and doors which according to the manual provided by the U.S. Department of Energy (www.energy.gov) should be categorized as insulation leakage and to use it as a means of ventilation is not recommended for its lack of measured control which will decrease Indoor Air Quality (IAQ). Controlled ventilation system is then the recommended approach on ventilation system to avoid insulation leakage through cracks on façade openings.

\section{BALCONY TYPES}

Balcony is one of the most essential architectural elements and comes in many forms and functions. Defined by its spatial configuration and geometrical forms, there are 3 types of balconies indicated by fig. 1 (Ribiero, 2020). The general forms of balconies are: 1) Open air balcony which includes recessed balcony (cantilevers, loggia, mashrabia, shaded and green balcony), 2) Glazed balcony which is separated from the outside by a glazed wall (sunspace or wintergarden), and 3) Eliminated balcony (balcony is integrated into indoor space). As evidenced in fig. 2 and fig. 3, open balconies comprised the majority in tropical and sub-tropical cities and urban areas.

In Indonesia, the tropical climate with yearround stable warm temperature opening many opportunities for balcony space utilization which is much demanded in the crowded urban environment where space is a premium. The most popular balcony model is a private balcony where $97 \%$ of respondents prefer 


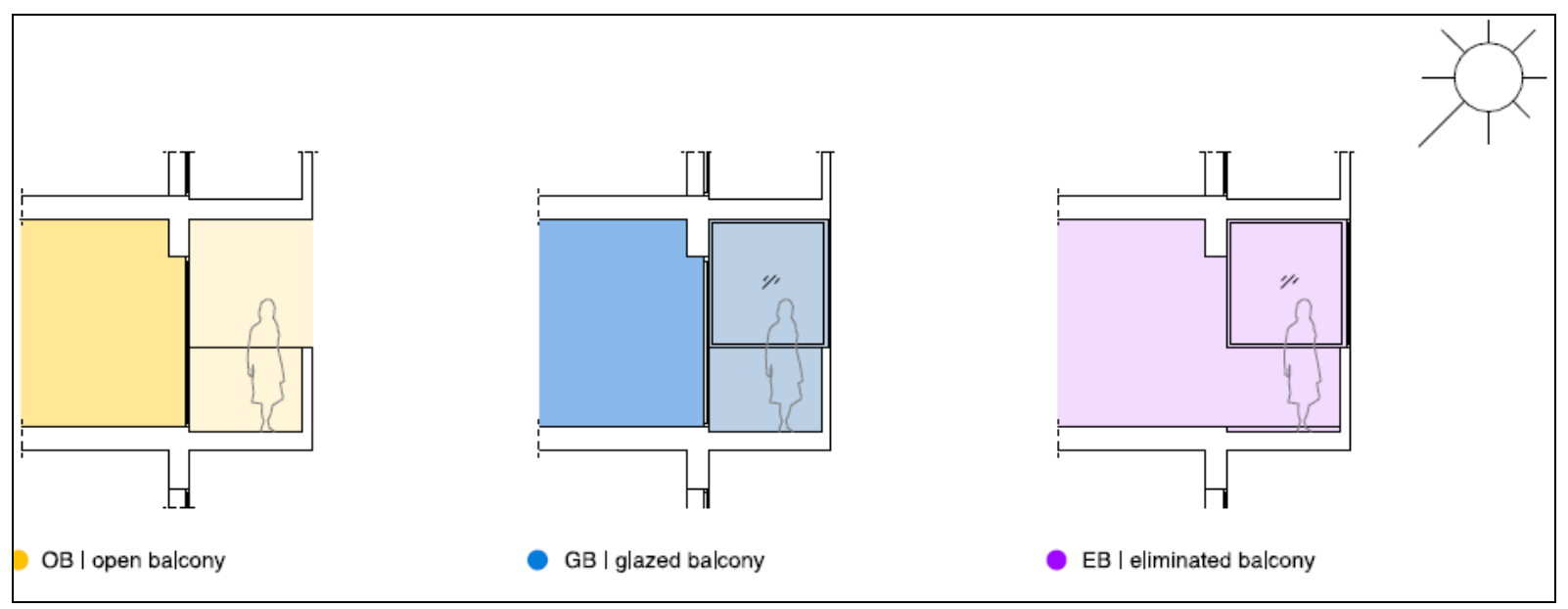

Fig. 1. Three types of balconies types with recessed balconies classified as an open balcony. (Source: Ribiero, 2020).

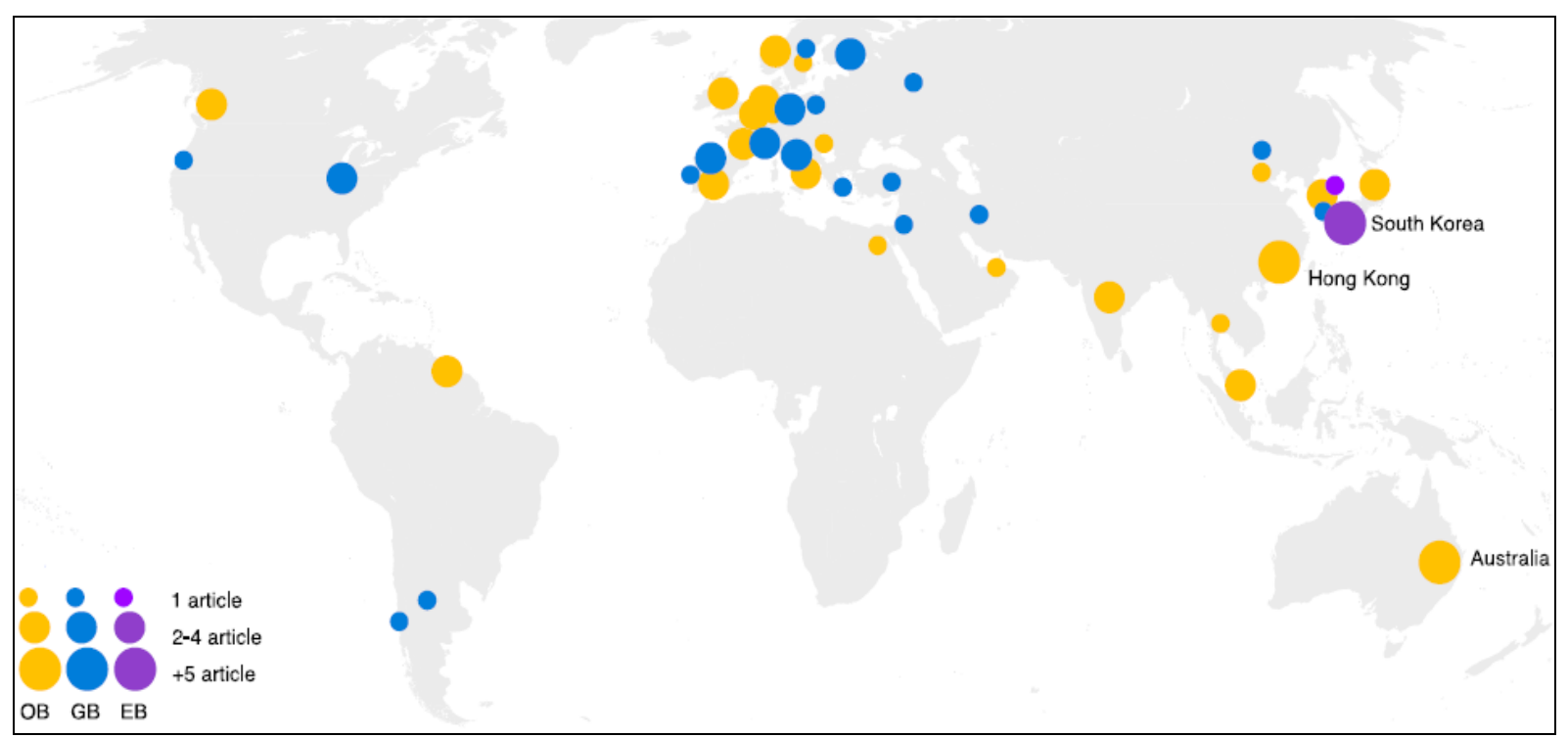

Fig, 2. Geographical distribution of each balcony types with recessed balconies classified as an open balcony. (Source: Ribiero, 2020).

a private balcony than a continuous or public balconies and $65 \%$ of respondents preferred recessed balconies protected by walls and cages (Kisnarini, 2018). This figure confirmed the survey collected by Ribiero (2020) in geographical distribution of balcony types but in the form of recessed open balconies. As much as $38 \%$ of people utilizing their balcony space through space adaptation or renovation for various reasons which is much higher compared to other types of adaptations such as corridor occupation, mezzanine construction and unit partitioning. Balcony spaces are in high demand and desirable in Indonesia owing to the culture and climate, but the placement of condenser units rendered the contained recessed space to be uncomfortable as indicated by the survey that the most popular activities in balcony are temporal activities e.g., clothes washing, dishwashing and storing food while the least is relaxing and studying.

\section{THEORETICAL FOUNDATION}

Balconies as architectural elements influences a building through airflow pattern transformation (Ribiero, 2020) which will improve interior natural ventilation, thermal comfort and reducing energy consumption through controlling air speed inside building. A building with an open balcony will have increased air speed velocity than any other types of balconies, while the depth of a balcony will decrease ventilation rates. As in recessed balconies or balconies with wing walls the depth and dimension of the space does not support wind induced ventilation (Chungloo, 2012). Other effects of balcony presence on a building's façade are the re-entry of ventilated air or the entry of pollutants present in the environment. The ventilation rate of an open balcony is estimated to be as high as $80 \%$ on an aerosol study of infectious 


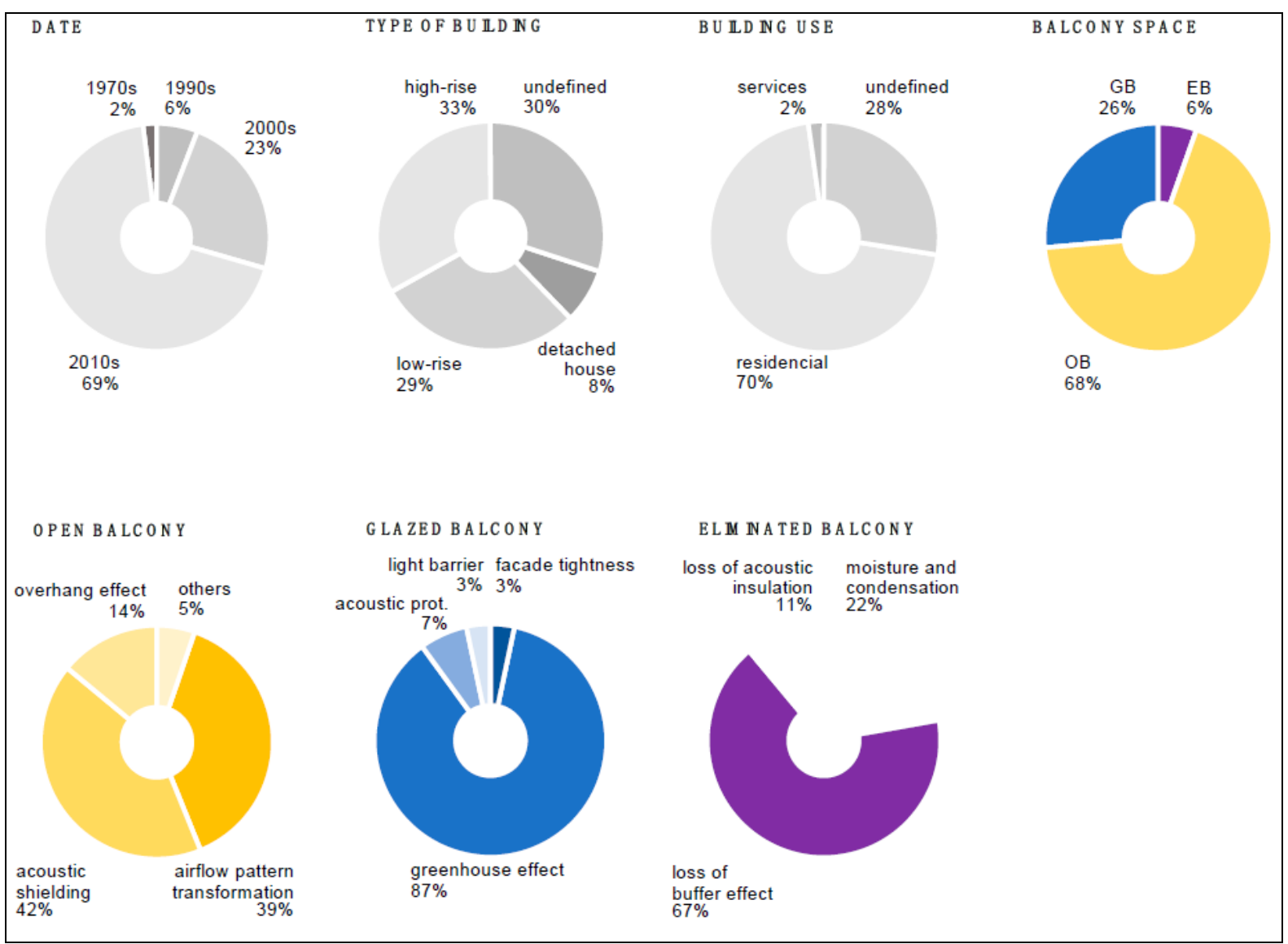

Fig. 3. Balcony type distribution on each building functions with1recessed balconies classified as an open balcony. (Source: Ribiero, 2020).

respiratory diseases, promoting infection transmission between units in a high-rise residential building through upward air currents.

Positive wind pressures are found on the surfaces of multi-story building's façade due to stack effect (Cammelli, 2016). This upward air current combined with the use of split-type air-conditioner where the condenser units are placed on each balcony upon each floor causes some negative effect on a building's thermal comfort and detrimental to the efficiency of condenser units' operation. A heat column effect will form where the two factors meet, accumulating high temperature air on the façade surface (Ranasinghe, 2016). This accumulated heat will permeate into the building's interior through the façade surface by the way of convection heating process. The energy is transferred to the solid façade surface from the heated air moving upwards as a liquid / gas system (Mintorogo, 2003).

An experiment by Nada and Said (2017) on a vertical arrangement of condenser units in a theoretical building shafts produces unsatisfactory thermal effect for the building. In their experiments conducted using computational fluid dynamic (CFD) high temperature air rises through the shaft to be dissipated but there is also a stagnant mass of high temperature air on each spot with a condenser placed. The effect was then enhanced proportionally to the building shaft's height due to the accumulation of high temperature air from lower units up toward the top of the building shaft. However, the high temperature air would be dissipated completely on upper levels closer to the to top of the building shaft aided with the suction effect from stack effect.

Another experiment was done by Chow (2002) using computational fluid dynamics (CFD) on a building in Hongkong with condenser units placed in groups inside a building re-entrant prepared specially for the arrangement. The experiment demonstrated that such condition to be less than ideal for the units' operation and energy efficiency. Analysis results obtained from CFD simulation and validated with energy evaluation by using Condenser Group Performance Indicator (CGPI) during summer month in Hongkong with the ambient temperature of $33^{\circ} \mathrm{C}$ which is similar to Surabaya city's average temperature indicates that CGPI value is proportional to building's height in which the condenser is placed. As indicated by CGPI evaluation, the dissipation of high temperature air accumulated in a heat column is dependent on façade surface air velocity which increases proportionally on taller surfaces. 


$$
\operatorname{CGPI}_{T_{\mathrm{r}}}\left(T_{\text {ref }}\right)=\frac{100}{n} \sum_{i=1}^{n}\left\{1-\left[\frac{\operatorname{COP}_{T_{\mathrm{r}}}\left(T_{0}\right)}{\operatorname{COP}_{T_{\mathrm{r}}}\left(T_{\mathrm{ref}}\right)}\right]_{i}\right\}
$$

Fig. 4. Condenser group performance indicator calculation used as validation. (Source: Chow, 2002).

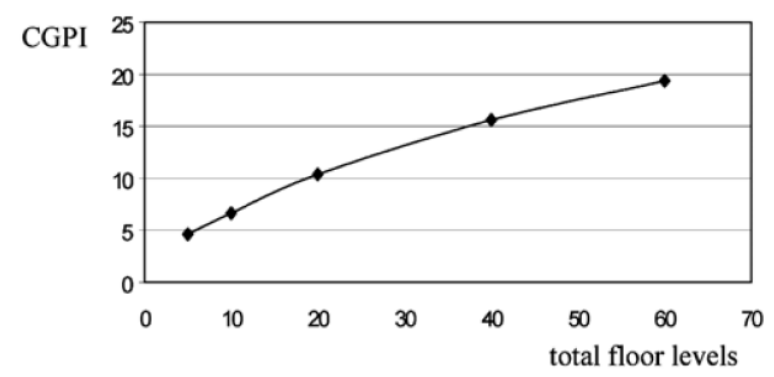

Fig. 5. CGPI values in proportion to building height. (Source: Chow, 2002).

\section{METHODOLOGY}

In evaluating the impact of recessed balcony model usage on a façade with a split-type air-conditioner condenser unit placed within it, an experiment using computational fluid dynamic (CFD) software based on real world building is used supplanted with relevant climate data to validate the result over the building's design. The designated experiment subject is Rosewood Tower in Darmo Hill Apartment Surabaya, a CAD model of the building was prepared to be analyzed using CFD and a qualitative analysis assessment is performed to evaluate the result from the simulation. Three simulation iterations were initiated under different façade height as independent variables to validate the consistency of the result relating with the height of the building and the control variables are: 1) façade design, 2) condenser unit placement, 3) building orientation, 4) Weather data, 5) Condenser capacity.

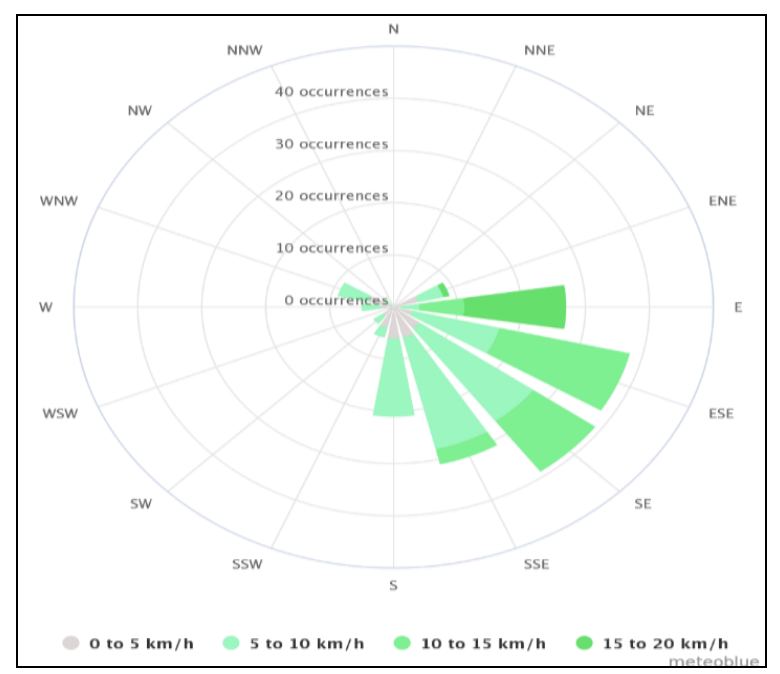

Fig. 6. Wind rose in Surabaya city. (Source: www.meteoblue.com).

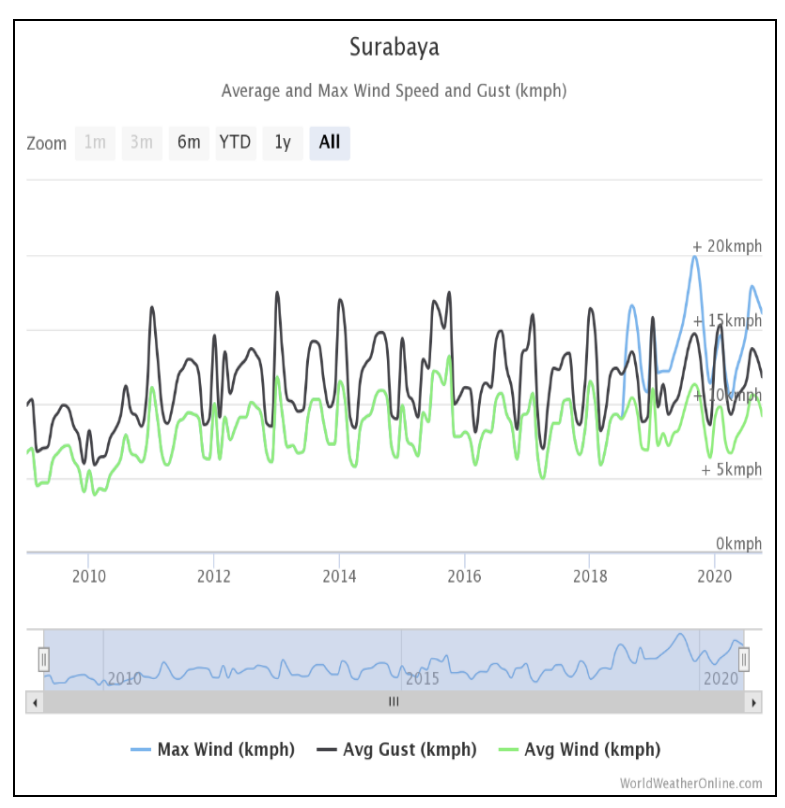

Fig. 7. Average wind speed in Surabaya city. (Source: www.worldweatheronline.com).

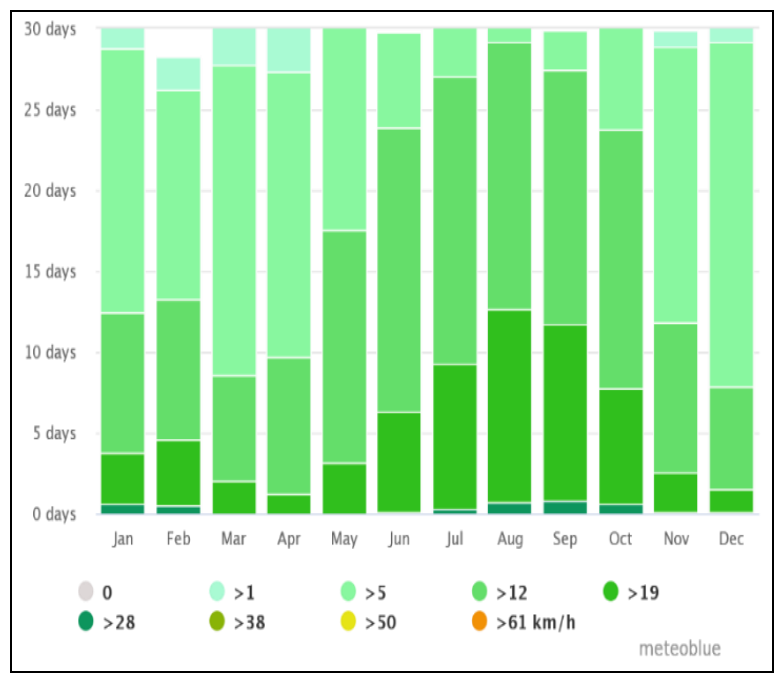

Fig. 8. Wind speeds in Surabaya city. (Source: www.meteoblue.com).

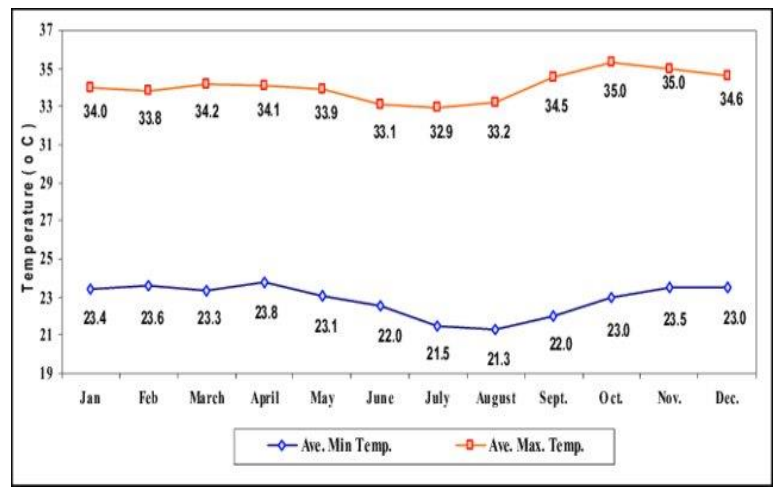

Fig. 9. Minimum and maximum monthly average temperature in Surabaya city from 1976 - 2001

(Source: Mintorogo, 2003). 


\begin{tabular}{|l|l|}
\hline TYPE OF AREA & W/M2 \\
\hline Residental & 100 \\
\hline Office & 120 \\
\hline Office - busy/with window & 140 \\
\hline Call centre & 150 \\
\hline Retail & 125 \\
\hline Comms/Server room & 200 \\
\hline Conservatory & 300 \\
\hline Doctor/Dentist & 120 \\
\hline Restaurant & 150 \\
\hline Gym & $150-180$ \\
\hline Public area & 120 \\
\hline
\end{tabular}

Fig. 10. Split-type air-conditioner energy usage. (Source: Daikin Corporation. Japan).

\section{RESULTS AND DISCUSSION}

To find out how air movements behave on façade geometry with recessed balconies, an experiment is carried out in 3 iterations of a façade model. The chosen model is based on a two-unit type A-1 Bedroom with a typical façade section facing south. The group is a mirror image equipped with a recessed balcony on 1,2-meter inset depth and the condenser units are placed laterally facing sideways. Access to balcony is an uninsulated aluminum framed window and the facade is equipped with external variation of 1,2 -meter vertical wall on one side. The model run in simulation using real world climate data acquired from various relevant sources to maintain the accuracy and validity of the experiments. The first iteration of the simulation follows the basic model with a 1 story façade height. The second, retains all the variables from the first iteration but the façade height is increased to 5 story. The third, follows all the variable in previous models and the façade height is further increased to 15 story to validate the scalability of the results from the previous simulations.

Model 1

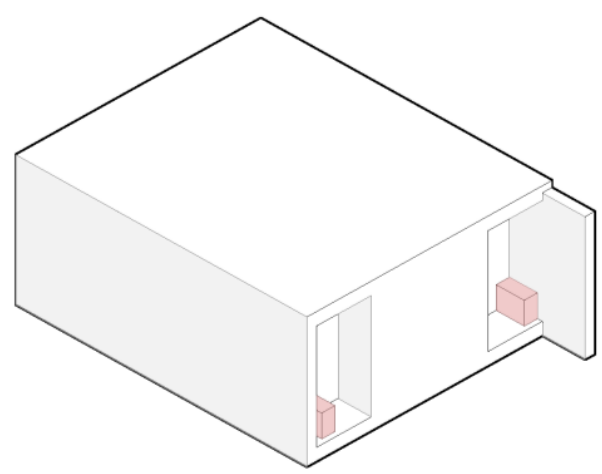

Fig. 11. Model 1 unit. (Source: author).

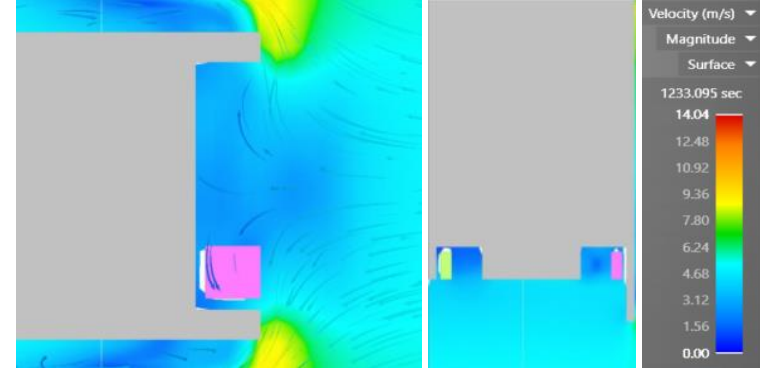

Fig. 12. Model 1 CFD velocity simulation.

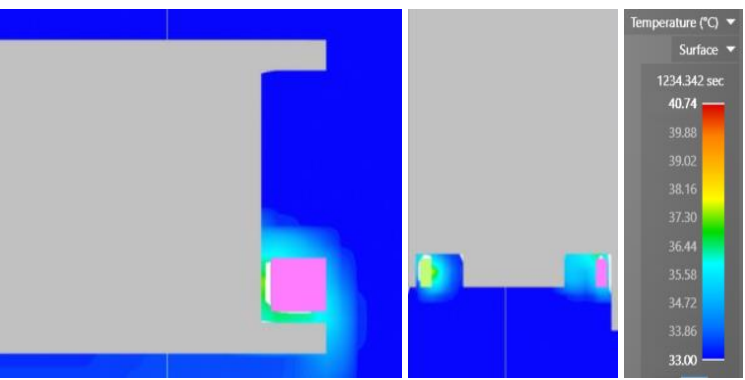

Fig. 13. Model 1 CFD temperature simulation.

The CFD simulation in fig. 13 indicates accumulation of high temperature air in the recessed balcony area of both units. Air movement in the recessed balcony space which formed a loggia/niche is restricted with the velocity reaching nearly zero in fig. 12 , causing high temperature air to be accumulated, confirmed in the theory of semi enclosed balcony depth causes a decrease of ventilation air speed (Ribeiro et.al., 2020). This heated air will permeate into the building's interior through convection from gas/liquid heat transfer to the solid façade.

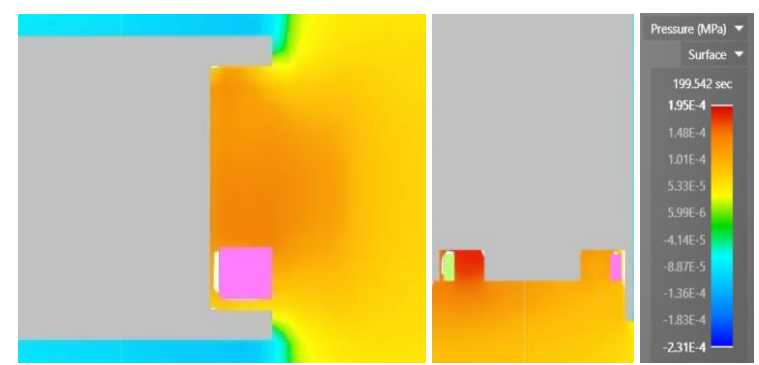

Fig. 14. Model 1 CFD pressure simulation.

The pressure CFD analysis in fig. 14 indicates the presence of positive air pressure area inside the recessed balcony where the extruded aluminum glass façade and balcony access is uninsulated. This is not recommended by U.S. Department of Energy in their article for home insulation, the heated air inside the balcony in fig. 13 will be pressed inward through cracks in window and door openings which leads to the transfer of air and temperature between the indoor and outdoor areas. 


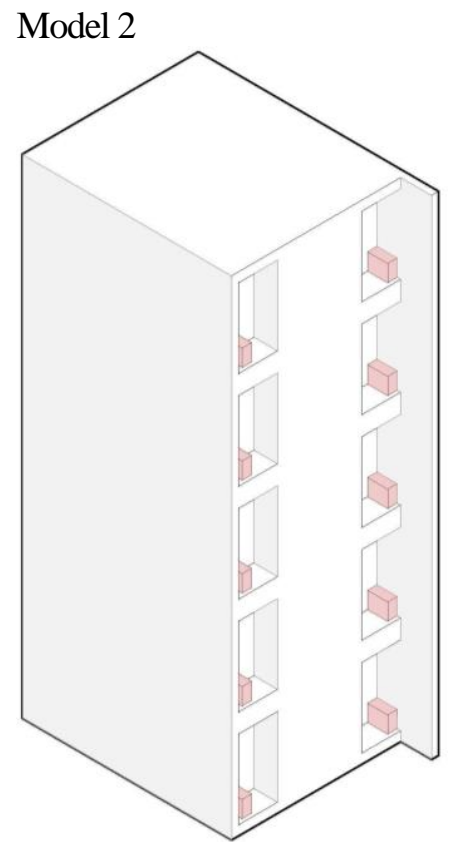

Fig. 15. Model 2 unit.
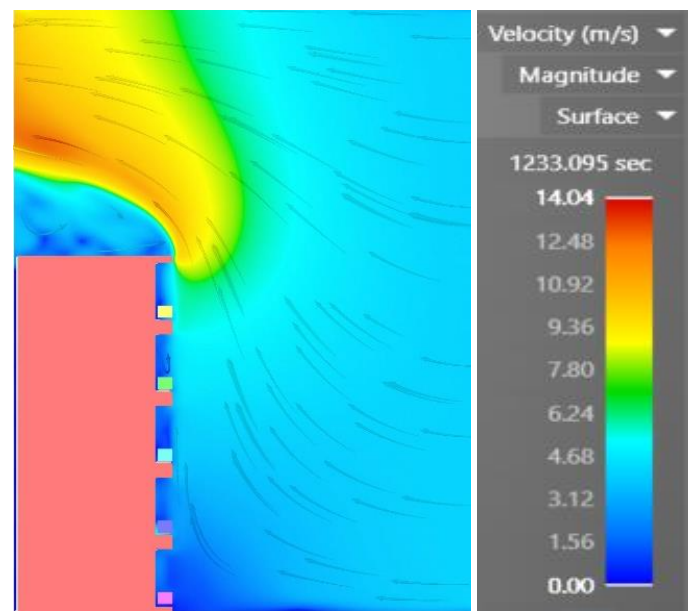

Fig. 16. Model 2 CFD velocity simulation. (Source: Prepared by author).
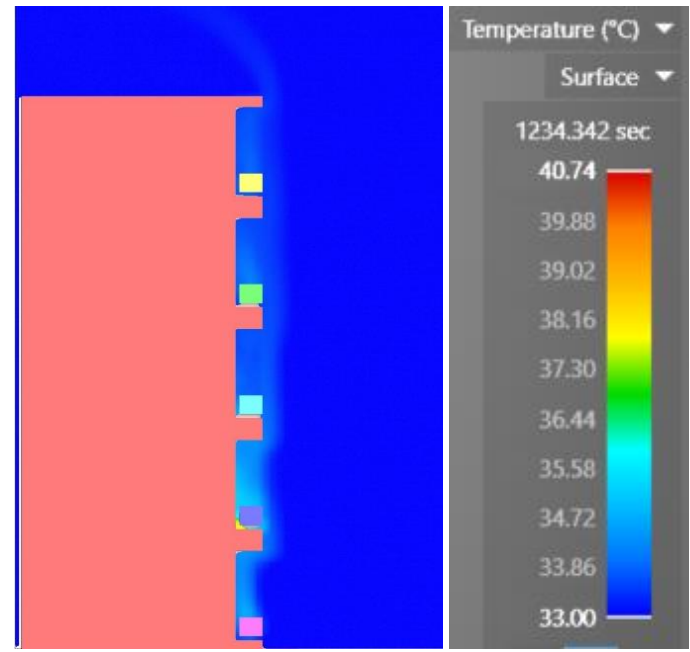

Fig. 17. Model 2 CFD temperature simulation.

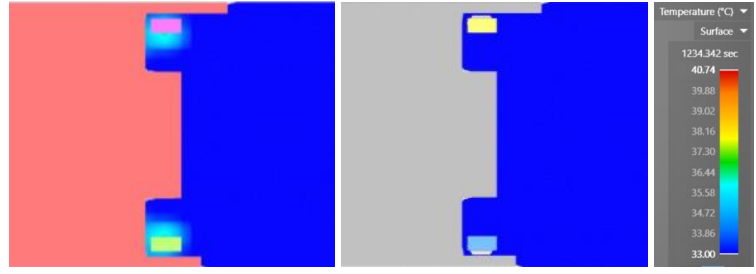

Fig. 18. Model 2 CFD temperature simulation on $1^{\text {st }}$ floor (left) and $5^{\text {th }}$ floor (right)

The CFD analysis in fig. 18 indicates accumulation of high temperature air inside recessed balcony area as also simulated on model 1 and the simulations indicates the presence of heat column in fig. 16 with a mass of heated air moving upwards to dissipate while leaving stagnating air inside the recessed balconies upon each floor, drawing similarities with other experiments undertaken by Ranasinghe (2016) as well as Nada and Said (2017) on condenser units' placement in building shafts and re-entrants. Heated air is accumulated in the lower floors as indicated in fig. 18, but the heat inside the balconies in the top floor is better dissipated due to the suction effect and air speed on façade surface exhibited in fig. 16.

\section{Model 3}

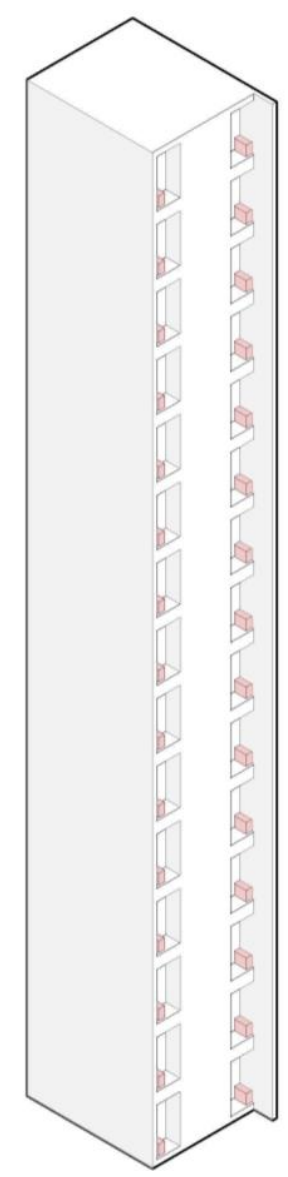

Fig. 19. Model 3 unit. 


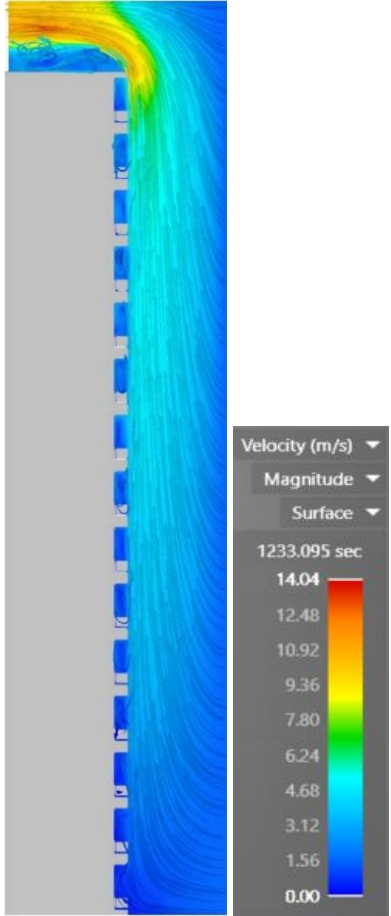

Fig. 20. Model 3 CFD velocity simulation.

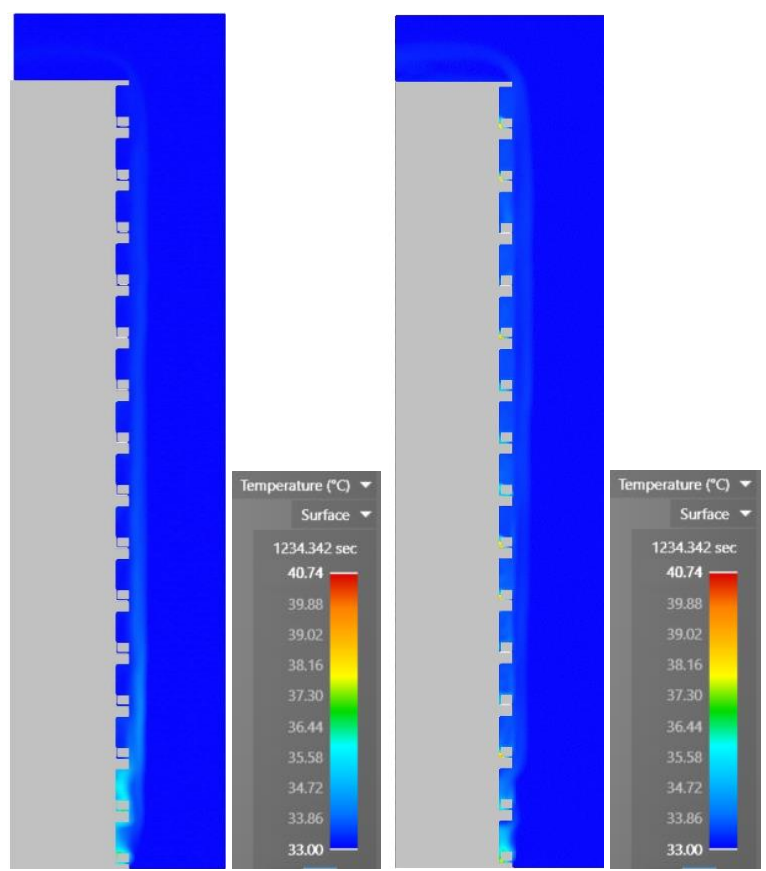

Fig. 21. Model 3 CFD temperature simulation on 2 lower condenser units operating (left) and all condenser units operating (right)

Data acquired from CFD simulation in fig. 20 indicates higher air movement velocity on façade surface toward the top of the building. However, air is stagnating inside the recessed balcony throughout the lower floors. The analysis in fig. 21 demonstrates all the features of the first two simulations with the accumulation of high temperature air mass on each recessed balcony with lower floors suffering a higher level of heat accumulation due to stagnating air trapped in the façade recesses and subsequently lower air velocity on façade surface.

\section{CONCLUSION}

A proper ventilation is essential in the façade design of buildings that utilize split-type air conditioning with condenser units placed inside recessed balconies on façade surface to maintain indoor environmental air quality, thermal comfort, and building's energy performance. Balconies play a significant role in influencing ventilation air speed between indoor and outdoor areas proportional to the depth and height of balcony placement on a façade surface on a multistory building. The geometry of recessed balconies causes stagnation of air movement on a façade surface, hindering the dissipation of high temperature air produced by condenser units as evidenced through the CFD simulations. A stacked recessed balcony array on a multi-story building sets up the formation of heat column which creates an accumulation of heated air on a façade surface and inside balcony recesses. The problem is intensified with the use of uninsulated extruded aluminum windows where air leakage enables the transfer of air mass and temperature between indoor zones and outdoor zones. This air movement through the façade works in combination with the heat transfer through convection from heated air accumulation further diminishing IAQ, thermal comfort and re-entry of pollutants from the outside.

The use of recessed balconies may be better suited in the upper stories closer to the top of the building where greater surface air velocities on the façade permits heat dissipation from stagnant air pockets inside the recessed balcony. The use of recessed balconies on the lower stories is undesirable due to lower façade surface air velocity promoting an accumulation of heated air in the recesses and heat column for the upper stories causing re-entries. The geometry of recessed balcony promotes a positive air pressure pressing on the façade surface, forming a stagnant air mass inside the recessed balcony and outside air re-entry on uninsulated openings inside.

There are several desirable solutions for this problem through façade design. A double façade may improve vertical air movements on the façade surface to accommodate ventilation purposes and preventing heated air re-entry into the building by decreasing air pressure onto the façade surface and the recessed balcony. Another solution is the use of permeable façade, enabling air movements between the balconies by eliminating solid surfaces which will enhance vertical air movement through perforations. 


\section{REFERENCES}

Air Sealing your home (October 16, 2020). Retrieved from: https://www.energy.gov/energysaver/ weatherize/air-sealing-your-home

Cammelli, S., \& Mijorski, S. (2016). Stack Effect in High-Rise Buildings: A Review. Sofia: International Journal of High-Rise Buildings, 5(4), 327-338.

Chungloow, S., \& Tienchutima, C. (2012). The Effect of Wing-Walls and Balcony on Wind Induced Ventilation in High-Rise Residential Units. Journal of Architectural/Planning Research and Studies (JARS), 8(1), 109-120.

Chow, T.T, Lin, Z., \& Liu, J.P. (2002). Effect of Condensing Unit Layout at Building Re-Entrant on Split Type Air Conditioner Performance, Hong Kong: Energy Build, 34, 237 - 244.

Kisnarini, R., Krisdianto, J., \& Indrawan, I.A., (2018). Contribution of Balcony of Rusunawa Surabaya on the Use of Space, Surabaya: IOP Conference Series: Earth and Environmental Science, 213 012039.
Mintorogo, D.S. (2003). Strategy Water Based Condenser: An Experimental Scale Model for Hybrid Passive Cooling Systems to Improve Indoor Temperature and Hot Water Utilities in Surabaya - Indonesia. Surabaya: Dimensi, Journal of Architecture and Built Environment, 31(2), 141-151.

Nada, S.A., \& Said, M.A. (2017). Performance and Energy Consumptions of Split Type Air Conditioning Units for Different Arrangements of Outdoor Units in Confined Building Shafts. Egypt: Applied Thermal Engineering, 123, 874 -890 .

Ranasinghe, C. (2016). Analysis of the Heat Column Formation in a 10 Story Building. Sri Lanka: University of Moratuwa.

Republik Indonesia: Peraturan Menteri Pekerjaan Umum Nomor: 2/PRT/M/2006. Tentang Pedoman Persyaratan Teknis Bangunan Gedung.

Ribeiro, C., Ramos, N., \& Flores-Colen, I. (2020). A Review of Balcony Impacts on the Indoor Environmental Quality of Dwellings. Lisboa, Portugal: MDPI Journal of Sutainability. 